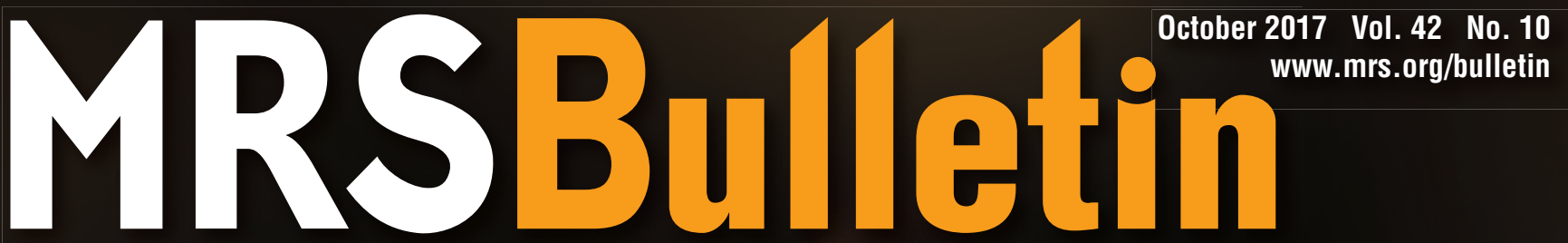

\begin{tabular}{l|l|l}
$M$ & $R$ & MATERIALS RESEARCH SOCIETY \\
Advancing materials. Improving the quality of life.
\end{tabular}

\title{
Materials under pressure
}

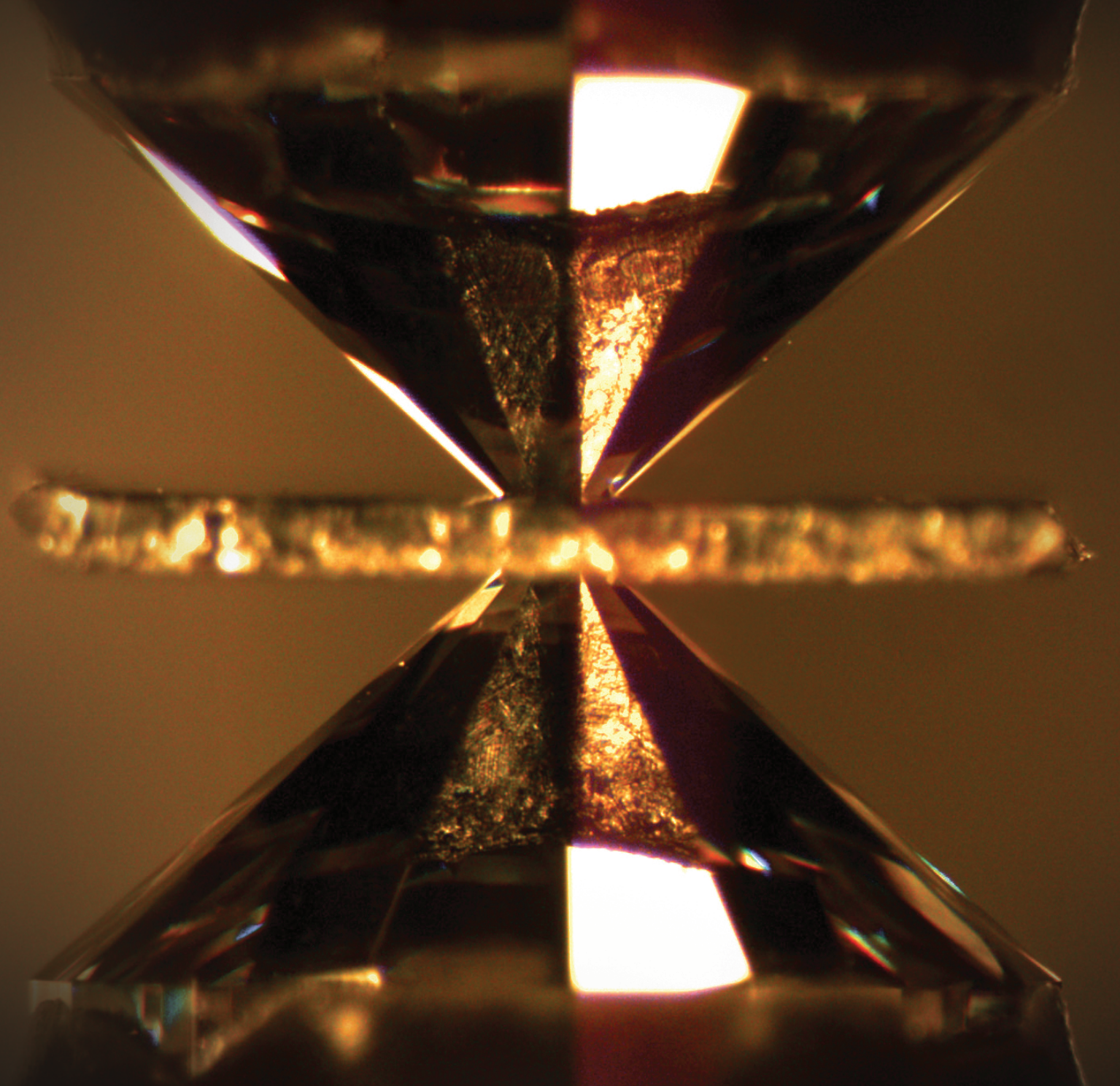

\section{ALSO IN THIS ISSUE}

Visualizing dynamic chemical

transformations in situ with

nanometer-scale resolution 


\section{CUSTOMIZED PRODUCTION ION IMPLANTERS}

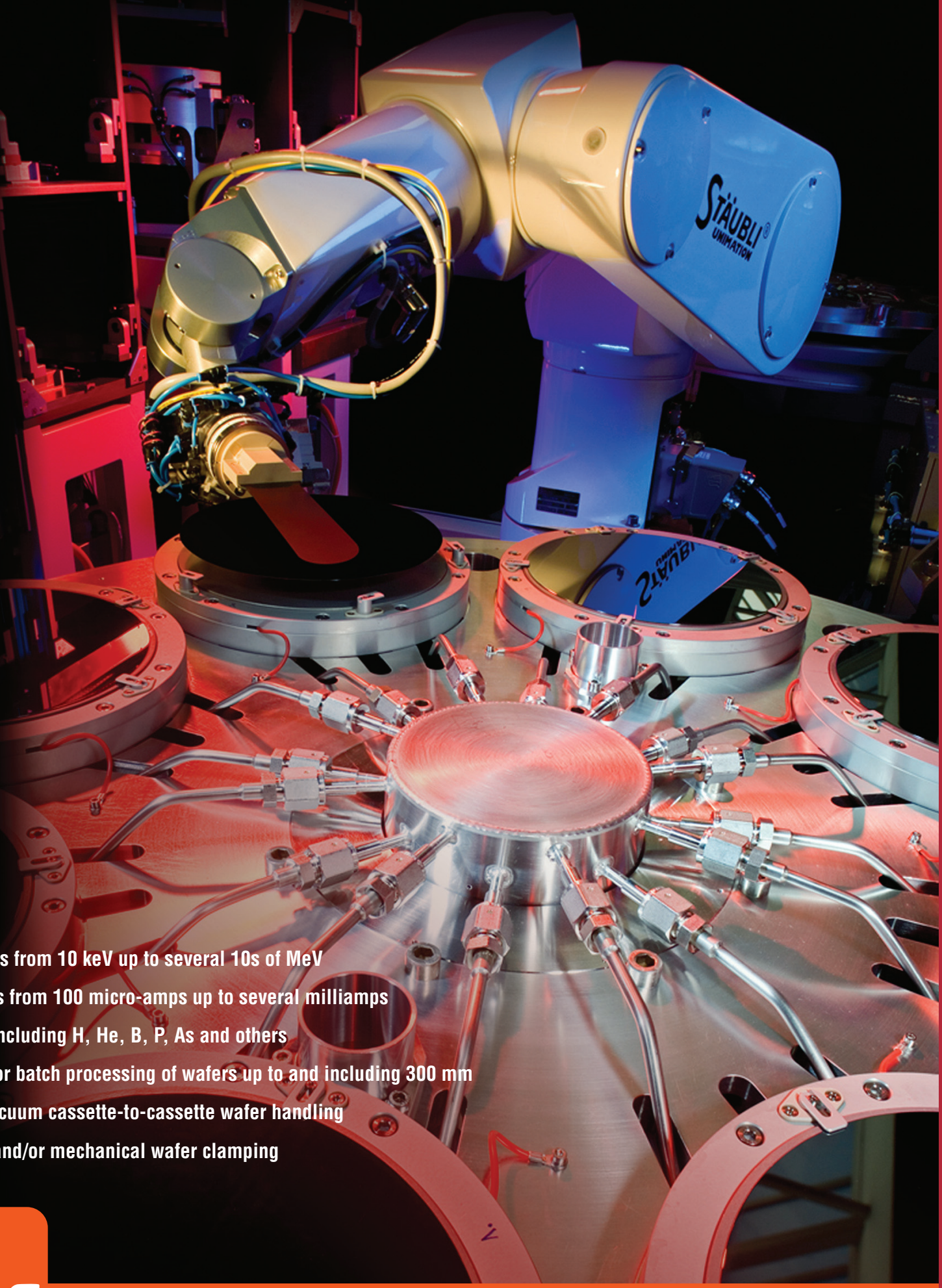

Beam energies from $10 \mathrm{keV}$ up to several $10 \mathrm{~s}$ of $\mathrm{Me}$

Beam currents from 100 micro-amps up to several milliamps

- Ion species, including $\mathrm{H}, \mathrm{He}, \mathrm{B}, \mathrm{P}, \mathrm{As}$ and others

Single wafer or batch processing of wafers up to and including $300 \mathrm{~mm}$

- In-air or in-vacuum cassette-to-cassette wafer handling

- Electrostatic and/or mechanical wafer clamping

\section{Hr High Voltage Engineering}

High Voltage Engineering Europa B.V.

P.O. Box 99, 3800 AB Amersfoort, The Netherlands

Tel: $31334619741 \cdot$ info@highvolteng.com

www.highvolteng.com 
The Norwegian Academy of Science and Letters announces the

\section{CALL FOR NOM I N ATONS 2018 \\ THE}

For outstanding scientific research in

\section{ASTROPHYSICS • NANOSCIENCE • NEUROSCIENCE}

Nomination deadline: December I, 2017

Nominations will be reviewed by committees of leading international scientists appointed by

The Norwegian Academy of Science and Letters based on recommendations by

The Chinese Academy of Sciences

The French Academy of Sciences

The Max Planck Society (Germany)

The National Academy of Sciences (US)

The Royal Society (UK)

The Kavli Prize will be awarded in Oslo in September 2018 and will consist of

\section{A gold medal • US \$1,000,000 • A scroll}

For details about the nomination process see

www.kavliprize.org

A partnership of

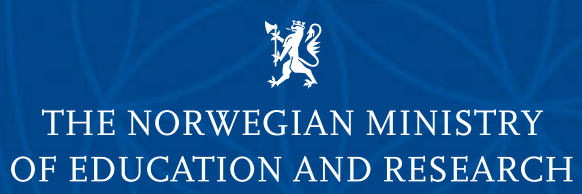

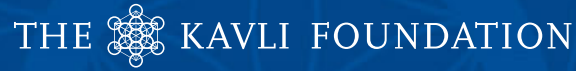




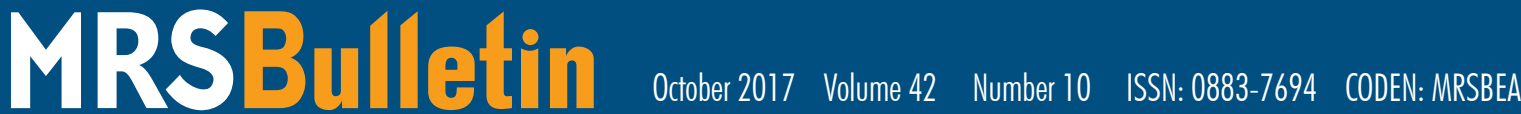
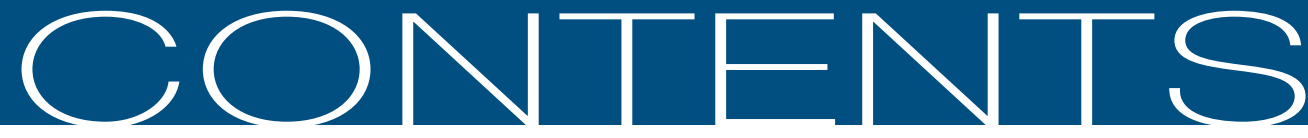

\section{MATERIALS UNDER PRESSURE}

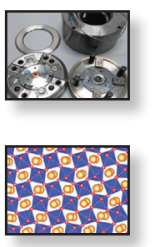

710 Materials under pressure

Anita Zeidler and Wilson A. Crichton, Guest Editors

714 Plastic deformation of materials under pressure

Philippe Carrez and Patrick Cordier

718 Chemistry at high pressure:

Tuning functional materials properties

Paolo Postorino and Lorenzo Malavasi

724 New states of matter and chemistry at extreme pressures: Low-Z extended solid Choong-Shik Yoo

729 Novel superhard nanopolycrystalline materials synthesized by direct conversion sintering under high pressure and high temperature

Hitoshi Sumiya

734 Impact of pressure on the structure of glass and its material properties

Philip S. Salmon and Liping Huang

738 Enzymatic activity under pressure

Claus Czeslik, Trung Quan Luong, and Roland Winter

\section{TECHNICAL FEATURE}

743 Inside out-Visualizing dynamic chemical transformations in situ with nanometer-scale resolution

MRS Outstanding Young Investigator Award Lecture 2017 MRS Spring Meeting

Jennifer A. Dionne

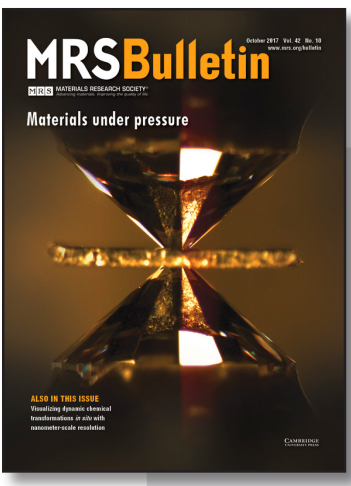

\section{ON THE COVER}

Materials under pressure. This issue of MRS Bulletin focuses on several of the many and diverse domains of advanced materials research where applied pressure or stress is used to alter or garner information on material properties. The application of high pressure - often combined with high temperatures and advanced analysis - has led to important technological progress. The cover shows a diamond anvil cell used to apply high pressures to materials. The diamond is $2.5 \mathrm{~mm}$ in height. A sample chamber is formed between the anvils inside a gasket made of rhenium metal. The diamond windows are transparent to a wide region of the electromagnetic spectrum for probing chemical reactions at high pressures and temperatures with UV-VIS-IR, lasers, neutrons, ultrasound, and $x$-rays or other forms of radiation. Image courtesy of Steven D. Jacobsen, Northwestern University. See the technical theme that appears on page $\mathbf{7 1 0}$. 


\section{DEPARTMENTS}

\section{OPINION}

Material Matters

Grabbing pebbles out of my shoes:

Thoughts of a grumpy old researcher on funding

Enrico Traversa

\section{NEWS \& ANALYSIS}

694 Materials News

- Research Highlights: Perovskites

Prachi Patel

FEATURE EDITOR: Pabitra K. Nayak

- Small tissue reprogramming device designed to heal damaged tissues

Joseph Bennington-Castro

- Shattering the myth of fast-flowing medieval glass Lauren Borja

- Quantum materials: Where many paths meet Philip Ball

\section{Science Policy}

- ARPA-E sees some success from basic energy research to societal impact Jennifer A. Nekuda Malik

- South Africa needs research plan for shale gas exploitation

\section{SOCIETY NEWS}

752 Preview: 2017 Materials Research Society Fall Meeting \& Exhibit

757 Profiles

Babak Anasori: Research assistant professor and microscopic photographer

Rahul Rao

\section{Upcoming Conference News}

- 9th International Conference of the African Materials Research Society to be held December 11-14

- Primer Encuentro de Jóvenes Investigadores en Ciencia de Materiales to be held April 13-14

\section{FEATURES}

708 Beyond the Lab

CuSTEMized: Inspiring girls in STEM through themselves Humaira Taz

758 Historical Note

A physicist remembers $\mathbf{3 0}$ years after the "Woodstock of Physics"

Tim Palucka

765 Books

- Materials Design Using Computational Intelligence Techniques

Shubhabrata Datta

Reviewed by Jeffery Aguiar

- Printed Electronics: Materials, Technologies and Applications

Zheng Cui

Reviewed by Jianguo Lu

- Stimuli-Responsive Materials: From Molecules to Nature Mimicking Materials Design

Marek W. Urban

Reviewed by Aurelia Meghea

768 Image Gallery

Look Again

\section{CAREER CENTRAL}

\section{ADVERTISERS IN THIS ISSUE}

American Elements

High Voltage Engineering

Kavli Foundation

Rigaku Corporation
Page No.

Outside back cover Inside front cover

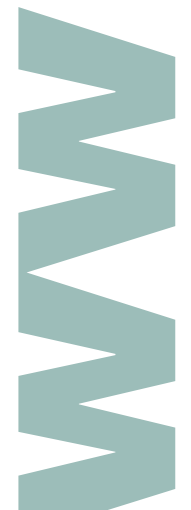

www.mrs.org/bulletin

www.mrs.org/energy-quarterly

www.mrs.org/mymrs

http://journals.cambridge.org

mrsbulletin-rss

@mrsbulletin 


\section{$\mathrm{M}|\mathrm{R}| \mathrm{S}$}

MATERIALS RESEARCH SOCIETY ${ }^{\circledR}$

Advancing materials. Improving the quality of life.
EDITORIAL OFFICE 506 Keystone Drive, Warrendale, PA 15086-7573 USA Bulletin@mrs.org tel 724.779.2747 fax 724.779.8313 www.mrs.org

\section{About the Materials Research Society}

The Materials Research Society (MRS), a not-for-profit scientific association founded in 1973 and headquartered in Warrendale, Pennsylvania, USA, promotes interdisciplinary materials research. Today, MRS is a growing, vibrant, member-driven organization of over 16,000 materials researchers spanning over 80 countries, from academia, industry, and government, and a recognized leader in the advancement of interdisciplinary materials research.

The Society's interdisciplinary approach differs from that of single-discipline professional societies because it promotes information exchange across many scientific and technical fields touching materials development. MRS conducts three major international annual meetings and also sponsors numerous single-topic scientific meetings. The Society recognizes professional and technical excellence and fosters technical interaction through University Chapters. In the international arena, MRS implements bilateral projects with partner organizations to benefit the worldwide materials community. The Materials Research Society Foundation helps the Society advance its mission by supporting various projects and initiatives.

\section{MRS BOARD OF DIRECTORS}

President Susan Trolier-McKinstry, The Pennsylvania State University, USA Immediate Past President Kristi S. Anseth, University of Colorado Boulder, USA Vice President and President-Elect Sean J. Hearne,

Sandia National Laboratories, USA

Secretary Eric A. Stach, University of Pennsylvania, USA

Treasurer David J. Parrillo, The Dow Chemical Company, USA

Executive Director Todd M. Osman, Materials Research Society, USA

Charles T. Black, Brookhaven National Laboratory, USA

Li-Chyong Chen, National Taiwan University, Taiwan

Matt Copel, IBM Research Division, USA

Paul S. Drzaic, Apple, Inc., USA

Dawnielle Farrar-Gaines, Johns Hopkins University, USA

Yury Gogotsi, Drexel University, USA

Claudia Gutiérrez-Wing, Instituto Nacional de Investigaciones Nucleares, Mexico

Young-Chang Joo, Seoul National University, South Korea

Karen L. Kavanagh, Simon Fraser University, Canada

Lincoln J. Lauhon, Northwestern University, USA

Christine Ortiz, Massachusetts Institute of Technology, USA

Sabrina Sartori, University of Oslo, Norway

Magaly Spector, The University of Texas at Dallas, USA

Molly M. Stevens, Imperial College London, UK

Anke Weidenkaff, University of Stuttgart, Germany

\section{MRS OPERATING COMMITTEE CHAIRS}

Academic Affairs Bruce M. Clemens, Stanford University, USA

Awards Albert Polman, FOM Institute AMOLF, The Netherlands

Government Affairs Kevin J. Whittlesey, 4D Molecular Therapeutics, USA

Meetings Terry Aselage, Sandia National Laboratories, USA

Member Engagement Sossina M. Haile, Northwestern University, USA

Public Outreach Elizabeth Kupp, The Pennsylvania State University, USA

Publications Shefford Baker, Cornell University, USA

\section{MRS HEADQUARTERS}

Todd M. Osman, Executive Director

J. Ardie Dillen, Director of Finance and Administration

Damon Dozier, Director of Government Affairs

Patricia Hastings, Director of Meetings Activities

Eileen M. Kiley, Director of Communications
Editor

Gopal R. Rao, rao@mrs.org

Managing Editor

Lori A. Wilson, Iwilson@mrs.org

News Editor

Judy Meiksin, meiksin@mrs.org

Technical Editor

Lisa C. Oldham, oldham@mrs.org

Editorial Assistants

Michelle S. Raley, raley@mrs.org

Mary Wilmoth

Associate Technical Editor

Tim Palucka

Production/Design

Andrea Pekelnicky-Frye, Rebecca Tokarczyk,

Felicia Turano, and TNQ

Associate Production Editor

Katie Wurtzel

Principal Development Editor

Elizabeth L. Fleischer

Director of Communications

Eileen M. Kiley
Guest Editors

Anita Zeidler and Wilson A. Crichton

Special Consultant

Angelika Veziridis

Energy Quarterly

George Crabtree (Co-chair),

Elizabeth A. Kócs (Co-chair),

Andrea Ambrosini, Monika Backhaus,

David Cahen, Russell R. Chianelli,

Shirley Meng, Sabrina Sartori, Anke

Weidenkaff, M. Stanley Whittingham,

and Steve M. Yalisove

Advertising/Sponsorship

Mary E. Kaufold, kaufold@mrs.org

Donna L. Watterson, watterson@mrs.org

Member Subscriptions

Michelle Judt, judt@mrs.org

Non-Member Subscriptions

subscriptions_newyork@cambridge.org
EDITORIAL BOARD

Fiona C. Meldrum (Chair), University of Leeds, UK

V.S. Arunachalam, Center for Study of Science, Technology \& Policy, India

Christopher J. Bettinger, Carnegie Mellon University, USA

Igor Lubomirsky, Weizmann Institute, Israe

Amit Misra, University of Michigan, USA

Steven C. Moss, The Aerospace Corporation, USA

Julie A. Nucci, Cornell University, USA

Linda J. Olafsen, Baylor University, USA

James W. Stasiak, HP Inc., USA

Carol Trager-Cowan, University of Strathclyde, UK

Eric Werwa, Washington, DC, USA

M. Stanley Whittingham, Binghamton University, The State University of New York, USA

Steve M. Yalisove, University of Michigan, USA

\section{VOLUME ORGANIZERS}

2017 Ken Haenen, Hasselt University \& IMEC vzw, Belgium John C. Mauro, The Pennsylvania State University, USA Michael S. Strano, Massachusetts Institute of Technology, USA Joyce Y. Wong, Boston University, USA

2018 Karsten Albe, Technische Universität Darmstadt, Germany Hiroshi Funakubo, Tokyo Institute of Technology, Japan Michael Hickner, The Pennsylvania State University, USA Bethanie Stadler, University of Minnesota, USA

2019 Craig B. Arnold, Princeton University, USA Claus Daniel, Oak Ridge National Laboratory, USA Seung Min Han, KAIST, South Korea Gabe Montano, Los Alamos National Laboratory/Northern Arizona University, USA

MRS Bulletin (ISSN: 0883-7694, print; ISSN 1938-1425, online) is published monthly by the Materials Research Society, 506 Keystone Drive, Warrendale, PA 15086-7573. @ 2017 Materials Research Society. Permission required to reproduce content. Periodical postage paid at New York, NY, and at additional mailing offices. POSTMASTER: Send address changes to MRS Bulleti in care of the Journals Department, Cambridge University Press, 100 Brook Hill Drive, West Nyack, NY 10994-2113, USA. Printed in the U.S.A.

Membership in MRS is $\$ 130$ annually for regular members, $\$ 32$ for students, and includes an electronic subscription to MRS Bulletin. Print subscriptions are available to MRS members for an additional $\$ 25$. Individual member subscriptions are for personal use only. Non-member subscription rates are $\$ 533$ (USD) for one calendar year (12 issues). Requests from subscribers for missing journal issues will be honored without charge only if received within six months of the issue's actual date of publication.

MRS Bulletin is included in Current Contents $\otimes /$ Engineering, Computing, and Technology; Current Contents ${ }^{\oplus / P h y s i c a l, ~ C h e m i c a l, ~ a n d ~ E a r t h ~ S c i e n c e s, ~ t h e ~ S c i S e a r c h ~}{ }^{\circledast}$ online database, Research Alert ${ }^{\oplus}$, Science Citation Index ${ }^{\oplus}$, and the Materials Science Citation Index ${ }^{\top M}$. Back volumes of MRS Bulletin are available on microfiche through University Microfilms Inc., 300 North Zeeb Road, Ann Arbor, MI 48106, USA

Authors of each technical article appearing in MRS Bulletin are solely responsible for all content in their article(s), including accuracy of the facts, statements, and citing resources. Facts and opinions are solely the personal statements of the respective authors and do not necessarily represent the views of the editors, the Materials Research Society, or Cambridge University Press.

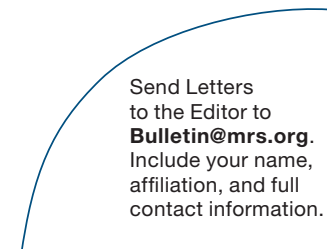

